\title{
ANALISIS PENGARUH KUALITAS SISTEM, CITRA MEREK, KEPERCAYAAN DAN ATRIBUT PRODUK TERHADAP KEPUASAN DAN DAMPAKNYA TERHADAP LOYALITAS PENGGUNA APLIKASI SNAPCHAT DI KOTA BANDUNG
}

\author{
Dahlia Br Ginting ${ }^{1}$ \\ Alan Setiawan \\ Sekolah Tinggi Manajemen Informatika dan Komputer LIKMI \\ Jl. Ir. H. Juanda 96 Bandung 40132 \\ Email : dahliaginting@yahoo.co.id ${ }^{1}$
}

\begin{abstract}
ABSTRAK
Sikap antusiasme masyarakat dunia terhadap hal-hal baru sangat luar biasa dan membuat para investor bersama developer aplikasi secara massal melakukan inovasi serta menawarkan produk mereka kepada khalayak dunia. Salah satu software yang kini sedang hangat diperbincangkan dan digunakan di seluruh dunia, yaitu Snapchat. Snapchat merupakan salah satu aplikasi yang masih menjadi trend saat ini.Snapchat menyediakan layanan berkirim pesan foto dan video.

Tujuan dari penelitian ini adalah untuk menganalisis pengaruh kualitas sistem, citra merek, kepercayaan, dan atribut produk terhadap kepuasan dan dampaknya terhadap loyalitas pengguna aplikasi snapchat di kota Bandung. Populasi dalam penelitian ini adalah para pengguna aplikasi snapchat. Teknik sampel yang digunakan adalah purposive sampling dengan jumlah sampel sebesar 300 responden.

Hasil penelitian juga menunjukkan bahwa adanya pengaruh tidak langsung kualitas sistem terhadap loyalitas melalui kepuasan sebesar 0.073 atau $7.3 \%$, pengaruh tidak langsung citra merek terhadap loyalitas melalui kepuasan sebesar 0.043 atau $4.3 \%$, pengaruh tidak langsung kepercayaan terhadap loyalitas melalui kepuasan sebesar 0.029 atau $2.9 \%$ danpengaruh tidak langsung atribut produk terhadap loyalitas melalui kepuasan sebesar 0.121 atau $12.1 \%$.
\end{abstract}

Kata kunci : kualitas sistem, citra merek, kepercayaan, atribut produk, kepuasan pengguna dan loyalitas pengguna.

\section{PENDAHULUAN}

Berbagai jenis produk software yang ditawarkan oleh developer software pun beraneka ragam, dari sistem operasi, media sosial, game, online shop, fotografi, dsb. Cara menggunakan beberapa software tersebut sangat mudah dan mungkin tidak asing untuk pengguna yang baru menggunakan perangkat smartphone maupun yang sudah lama menggunakannya. Software pun kini menjadi peran penting dalam perkembangan perangkat smartphone. Beberapa software kini mulai menerapkan standar minimum untuk spesifikasi suatu perangkat agar software yang dibuatnya dapat berjalan menyesuaikan perkembangan smartphone yang ada.

Salah satu aplikasi yang menjadi trend saat ini yaitu Snapchat. Snapchatsangat populer di kalangan anak muda dengan rentang umur 17 tahun hingga 35 tahun. Snapchat 
menyediakan layanan berkirim pesan foto dan video. Uniknya, foto dan video itu akan hilang tanpa jejak beberapa saat setelah dilihat oleh penerima. Pengirim dapat mengatur berapa lama foto dan video itu dapat dilihat oleh penerima hingga akhirnya hilang. Ini merupakan hal yang menakjubkan bagi Snapchat dan orang-orang yang melatarbelakangi Snapchat hingga menjadi besar seperti sekarang. Snapchat pun terus mengembangkan fitur-fitur yang ada agar para penggunanya tidak merasa jenuh. Maka dari itu, Snapchat selalu berada pada rating 30 teratas dalam perangkat iOS ataupun Android.

Melihat potensi dari perkembangan software Snapchat ini, maka dilakukan penelitian tentang analisis pengaruh kualitas system, citra merek, kepercayaan, dan atribut produk terhadap kepuasan serta dampaknya terhadap loyalitas pengguna aplikasi Snapchat.

\section{TELAAH PUSTAKA}

\subsection{KUALITAS SISTEM APLIKASI INFORMASI}

Ada beberapa definisi tentang kualitas sistem aplikasi yang dikemukakan oleh banyak pakar, diantaranya yang dikemukakan (Sutabri, 2012: 32) menyatakan bahwakualitas sistem berarti berfokus kepada performa sistem informasi yang terdiri dari perangkat keras, perangkat lunak, kebijakan, dan prosedur yang dapat menyediakan informasi yang dibutuhkan oleh pengguna.

Beberapa peneliti telah menggunakan beberapa indikator pengukuran untuk mengukur kualitas sebuah sistem aplikasi. Menurut Indriani dan Adryan, variabel kualitas sistem dapat diukur dengan menggunakan indikator (Indriani, 2009: 82-83):

a. Keandalan (reliability)

Keandalan digunakan untuk menyatakan kemampuan perangkat lunak untuk tetap dapat beroperasi tanpa mengalami gangguan (error) yang berarti dalam jangka waktu yang lama. Keandalan dalam sistem mencerminkan kualitas sistem perangkat lunak.

b. Kemudahan penggunaan (ease of use)

Kemudahan penggunaan merupakan suatu tingkatan dimana seseorang percaya bahwa penggunaan teknologi sistem informasi tidak memerlukan usaha yang keras melainkan mudah untuk dipahami dan digunakan.

c. Fleksibilitas (flexibility)

Fleksibilitas digunakan untuk menyatakan kemampuan sistem dari sebuah perangkat lunak mudah dimodifikasi, ditambah atau dihapus komponennya.

d. Fungsionalitas (functionality)

Fungsionalitas melihat apakah suatu sistem sudah sesuai dengan kebutuhan.

Indikator kualitas sistem menurut Nelson, Todd dan Wixom yang dikutip oleh Khusumah, adalah sebagai berikut (Khusumah, 2014: 16) :

a. Fleksibilitas sistem

Sistem dapat disesuaikan dengan berbagai kebutuhan pengguna dan dengan kondisi yang berubah-ubah.

b. Aksesibilitas sistem

Kemudahan untuk mengakses informasi ataupun kemudahan untuk menghasilkan informasi dari suatu sistem.

c. Waktu respon sistem

Mengasumsikan respon sistem yang cepat atau tepat waktu terhadap permintaan informasi.

d. Akurat

Informasi harus bebas dari kesalahan-kesalahan dan tidak menyesatkan. Informasi harus memiliki keakuratan tertentu agar tidak diragukan kebenarannya.

e. Tepat pada waktunya 
Informasi yang datang kepada penerima tidak boleh terlambat, karena informasi yang tidak tepat waktu sudah tidak bernilai.

f. Relevan

Informasi yang ada memiliki nilai dan bermanfaat sesuai dengan yang diperlukan pengguna.

g. Dapat dipahami

Sistem menghasilkan informasi yang dapat dipahami, dengan kata lain informasi harus disajikan dalam bentuk yang dapat dimengerti serta jelas.

h. Lengkap

Informasi dikatakan lengkap jika tidak meninggalkan aspek-aspek penting dari kejadian yang merupakan dasar masalah atau aktivitas-aktivitas yang diukurnya.

i. Reliability

Sistem dapat digunakan kembali dengan mudah meskipun pengguna sudah lama tidak menggunakannya, dan pengguna baru dapat dengan mudah menggunakannya.

\subsection{CITRA MEREK}

Citra merek (brand image) memiliki peranan penting dalam berkembangnya sebuah merek. Hal ini menyangkut mengenai reputasi serta kredibilitas merek yang kemudian menjadi sebuah acuan konsumen (pengguna) dalam mencoba atau menggunakan produk barang atau jasa tersebut.Ada beberapa defenisi tentang citra merek, antara lain yang dikemukakan oleh (Saputri, 2014: 195) menyatakan bahwa brand image (citra merek) adalah kesan yang muncul dan dirasakan oleh konsumen terhadap suatu brand yang tersimpan dalam ingatan konsumen dan dapat memengaruhi perilaku konsumen.

Beberapa peneliti telah menggunakan beberapa indikator pengukuran untuk mengukur citra merek suatu sistem aplikasi.

Menurut Keller yang dikutip oleh Saputri dan Pranata, variabel citra merek dapat diukur dengan indikator, sebagai berikut (Saputri, 2009: 195) :

a. Keunggulan asosiasi merek (favorability of brand association)

Keunggulan asosiasi merek dapat membuat konsumen percaya bahwa atribut dan manfaat yang diberikan oleh suatu brand dapat memuaskan kebutuhan dan keinginan konsumen sehingga menciptakan sikap yang positif terhadap brand tersebut.

b. Kekuatan asosiasi merek (strenght of brand association)

Kekuatan asosiasi merek bergantung pada bagaimana informasi masuk dalam ingatan konsumen dan bagaimana informasi tersebut dikelola oleh data sensoris di otak sebagai bagian dari brand image. Ketika konsumen secara aktif memikirkan dan menguraikan arti informasi pada suatu produk atau jasa, akan tercipta asosiasi yang semakin kuat pada ingatan konsumen.

c. Keunikan asosiasi merek (uniqueness of brand association)

Sebuah brand haruslah unik dan menarik sehingga produk tersebut memiliki ciri khas dan sulit ditiru para pesaing. Keunikan suatu produk akan memberikan kesan yang cukup membekas terhadap ingatan pelanggan akan keunikan brand.

Sebuah brand yang memiliki ciri khas haruslah dapat melahirkan keinginan pelanggan untuk mengetahui lebih jauh dimensi brand yang terkandung di dalamnya.

Menurut pernyataan Hoeffler dan Keller yang dikutip oleh Amanah, dimensi atau indikator yang memperngaruhi citra merek (brand image), yaitu (Amanah, 2011: 227) :

a. Kesan profesional

Produk memiliki kesan profesional atau memiliki keahlian dibidangnya.

b. Kesan modern

Produk memiiiki kesan modern atau memiliki teknologi yang selalu mengikuti perkembangan jaman. 
c. Melayani semua segmen

Produk mempu melayani semua segmen yang ada, tidak hanya melayani segmen khusus saja.

d. Perhatian pada konsumen

Produk perhatian/peduli pada keinginan/kebutuhan konsumen.

\subsection{KEPERCAYAAN}

Pondasi utama dalam suatu bisnis yaitu kepercayaan. Kepercayaan itu yang mendorong konsumen untuk bertahan serta merekomendasikan kepada calon konsumen dan menjadi sebuah siklus bisnis agar bisnis dapat terus berjalan.

Kepercayaan adalah kesediaan perusahaan untuk bergantung pada mitra bisnis (Kotler, 2007). Pengertian kepercayaan menurut (Sari, 2012 ) merupakan keadaan psikologis yang terdiri dari maksud untuk menerima keretanan didasarkan pada perilaku harapan positif dari niat atau perilaku lain. Beberapa peneliti telah menggunakan beberapa indikator pengukuran untuk mengukur kepercayaan terhadap suatu sistem aplikasi.

Menurut Mayer, Davis, dan Schoorman yang dikutip oleh Anggriawan dan Kridasusila, variabel kepercayaan dapat diukur menggunakan indikator, (Anggriawan, 2012: 85) :

a. Kemampuan adalah sesuatu yang berhubungan dengan keahlian, kompetensi, dan karakter yang mana satu pihak dapat mempengaruhi dengan beberapa spesifikasi tertentu.

b. Kebaikan adalah tingkat kepercayaan di mana seorang yang dipercayai akan percaya bahwa akan melakukan hal yang baik ke orang yang memberikan kepercayaan.

c. Integritas adalah orang yang percaya akan selalu berkeinginan untuk mengikuti prinsip-prinsip dimana orang yang memberikan kepercayaan akan menerimanya.

Menurut Mukherjee dan Nath yang dikutip oleh Maharsi, terdapat tiga indikator yang mempengaruhi variabel kepercayaan, yaitu (Maharsi, 2006: 37) :

a. Orientasi teknologi (technology orientation)

Orientasi konsumen terhadap teknologi mewakili kepercayaan. Apabila sebuah produk sudah memenuhi orientasi dari konsumen tersebut maka kepercayaan akan timbul.

b. Reputasi (reputation)

Reputasi adalah faktor sangat penting dari kepercayaan, ketika konsumen merasa perusahaan memiliki reputasi yang buruk maka konsumen akan enggan untuk berhubungan dengan perusahaan tersebut.

c. Persepsi resiko (perceived risk)

Besarnya persepsi konsumen mengenai resiko memperngaruhi besarnya kepercayaan. Konsumen yang mengganggap terdapat resiko yang tinggi dalam mengkonsumsi atau menggunakan suatu produk atau jasa maka akan mengurangi tingkat kepercayaan konsumen tersebut terhadap produk atau jasa yang bersangkutan.

\subsection{ATRIBUT PRODUK}

Atribut produk dapat diartikan sebagai karakteristik yang melengkapi fungsi dasar produk.Pengertian atribut produk yang dikemukakan oleh Nugroho (2015)merupakan suatu bentuk komponen, sifat, rancangan serta unsur lainnya yang dipandang penting oleh konsumen dan dijadikan dasar dalam pengambilan keputusan pemakaian produk. Beberapa peneliti telah menggunakan beberapa indikator pengukuran untuk mengukur atribut produk.

Menurut (Handayani, 2012: 2), variabel atribut produk dapat diukur dengan indikator, sebagai berikut:

a. Kualitas produk 
Kualitas produk merupakan tingkat mutu yang diharapkan dan pengendalian keragaman dalam mencapai mutu tersebut untuk memenuhi kebutuhan konsumen.

b. Desain

Desain merupakan totalitas fitur yang mempengaruhi tampilan, rasa, dan fungsi produk berdasarkan kebutuhan pelanggan.

c. Warna

Warna merupakan salah satu dimensi yang dipertimbangkan konsumen dalam memilih produk.

d. Label produk

Label produk merupakan bagian dari sebuah barang berupa keterangan-keterangan tentang produk tersebut.

e. Estetika produk

Estetika produk merupakan karakteristik yang bersifat subyektif mengenai nilai-nilai estetik yang berkaitan dengan pertimbangan pribadi dan refleksi dari preferensi individual.

Menurut Kotler dan Armstrong yang dikutip oleh Yuliastanto (2010: 25-26), variabel atribut produk dapat diukur dengan menggunakan tiga indikator, yaitu:

a. Kualitas

Kualitas adalah kemampuan suatu produk untuk melakukan fungsi-fungsinya. Kemampuan itu meliputi daya tahan, kehandalan, ketelitian yang dihasilkan, kemudahan dioperasikan dan diperbaiki, dan atribut lain yang berharga pada produk secara keseluruhan.

b. Fitur

Fitur merupakan alat persaingan untuk mendeferensiasikan produk perusahaan terhadap produk sejenis yang menjadi pesaingnya, menjadi produsen awal yang mengenalkan fitur baru yang dibutuhkan dan dianggap bernilai menjadi salah satu cara efektif untuk bersaing.

c. Gaya dan desain produk

Gaya semata-mata menjelaskan penampilan produk tertentu. Gaya mengedepankan tampilan luar dan tidak membuat orang bosan. Gaya yang sensasional mungkin akan mendapatkan perhatian dan mempunyai nilai seni, tetapi tidak selalu membuat produk tertentu berkinerja dengan baik. Berbeda dengan gaya, desain memberikan kontribusi dalam hal kegunaan produk dan juga penampilannya. Gaya dan desain yang baik dapat menarik perhatian, meningkatkan kinerja produk, memotong biaya produksi dan memberikan keunggulan bersaing.

\subsection{KEPUASAN}

Kepuasan konsumen merupakan salah satu inti filsafat konsep pemasaran. Kepuasan pelanggan merupakan salah satu faktor untuk mengukur keberhasilan bagi setiap pengembangan dan implementasi sistem aplikasi informasi pada suatu perusahaan.

Tujuan utama dari suatu bisnis yaitu konsumen (pengguna) mendapat kepuasan dari sebuah produk bisnis yang dibuat oleh perusahaan.Kepuasan konsumen adalah perasaan senang atau kecewa seseorang yang timbul karena membandingkan kinerja yang dipersepsikan produk (atau hasil) terhadap ekspektasi mereka (Kotler, 2007: 139). Beberapa peneliti telah menggunakan beberapa indikator pengukuran untuk mengukur kepuasan suatu sistem aplikasi.

Menurut Selnes, Goodman, dan Geykens yang dikutip oleh Sunarto, variabel kepuasan pengguna dapat diukur menggunakan indikator, yaitu (Sunarto, 2006: 12-13) :

a. Rasa senang 
Rasa senang menunjukan sejauh mana konsumen merasa senang dengan pengalaman dalam menggunakan suatu produk atau jasa.

b. Kepuasan terhadap pelayanan

Kepuasan terhadap pelayanan menunjukkan sejauh mana para konsumen merasa puas dengan pelayanan suatu sistem.

c. Kepuasan terhadap sistem

Kepuasan terhadap sistem menunjukkan sejauh mana kecepatan dan kemudahan sistem digunakan oleh konsumen.

d. Kepuasan finansial

Kepuasan konsumen secara finansial menunjukkan sejauh mana konsumen merasa puas atas biaya yang dikeluarkan untuk dapat mengkonsumsi produk/jasa.

Terdapat empat indikator untuk mengukur kepuasan pengguna menurut Irawan, yaitu (Irawan, 2008: 37) :

a. Kualitas produk

Konsumen akan merasa puas apabila konsumen merasa produk yang digunakan berkualitas.

b. Kualitas pelayanan atau jasa

Konsumen akan merasa puas ketika mendapatkan pelayanan yang dengan harapan.

c. Harga

Konsumen akan merasa puas ketika mengeluarkan biaya yang sesuai bahkan melebihi dari manfaat yang dirasakan ketika menggunakan suatu produk.

d. Kemudahan

Konsumen akan merasa puas jika dapat dengan mudah mendapatkan dan menggunakan suatu produk.

\subsection{LOYALITAS PENGGUNA}

Loyalitas merupakan suatu sikap positif konsumen terhadap suatu produk atau jasa yang disertai dengan pembelian berulang dan bersifat konsisten, yang selanjutnya mereka atau konsumen merekomendasikan produk atau jasa perusahaan tersebut kepada orang lain dan juga konsumen tidak beralih ke produk lainnya (Yuliastanto, 2010). Beberapa peneliti telah menggunakan beberapa indikator pengukuran untuk mengukur citra merek suatu sistem aplikasi.

Menurut Griffin yang dikutip oleh Saputri dan Pranata, variabel loyalitas pengguna dapat diukur dengan indikator, sebagai berikut (Saputri, 2014: 180) :

a. Repurchase / repeated use

Melakukan pembelian atau penggunaan ulang secara teratur.

b. Purchases across product and service line

Melakukan pembelian lini produk lainnya.

c. Retention

Menunjukkan kekebalan terhadap tarikan dari pesaing atau tidak mudah terpengaruh oleh bujukan pesaing.

d. Referral

Memberikan referensi pada orang lain.

Sedangkan menurut Agus Supandi Soegoto, terdapat lima indikator yang dapat mempengaruhi loyalitas, yaitu (Soegoto, 2013: 1274):

a. Kepuasan (statisfaction)

Kepuasan konsumen merupakan perbandingan antara harapan sebelum melakukan pembelian dengan kinerja yang dirasakan.

b. Ikatan emosi (emotional bonding) 
Dimana konsumen dapat terpengaruh oleh sebuah merek yang memiliki daya tarik tersendiri sehingga konsumen dapat diidentifikasikan dalam sebuah merek, karena sebuah merek dapat mencerminkan karakteristik konsumen tersebut. Ikatan yang tercipta dari sebuah merek ialah ketika konsumen merasakan ikatan yang kuat dengan konsumen lain yang menggunakan produk atau jasa yang sama.

c. Kepercayaan (trust)

Kemauan seseorang untuk mempercayakan perusahaan atau sebuah merek untuk melakukan atau menjalankan sebuah fungsi.

d. Pengalaman terhadap perusahaan (history with the company)

Sebuah pengalaman seseorang pada perusahaan dapat membentuk perilaku. Ketika konsumen mendapatkan pelayanan yang baik dari perusahaan, maka konsumen akan mengulangi perrilaku tersebut pada perusahaan.

e. Kemudahan (choice reduction and habit)

Konsumen akan merasa nyaman dengan sebuah merek ketika konsumen merasakan kemudahan dalam menggunakan atau mendapatkan suatu produk atau jasa. Kemudahan akan berpengaruh terhadap keputusan untuk melakukan pembelian atau penggunaan ulang

\section{MODEL PENELITIAN}

Gambar 1.

Kerangka pemikiran teoritis dan rumusan hipotesis penelitian disajikan seperti pada

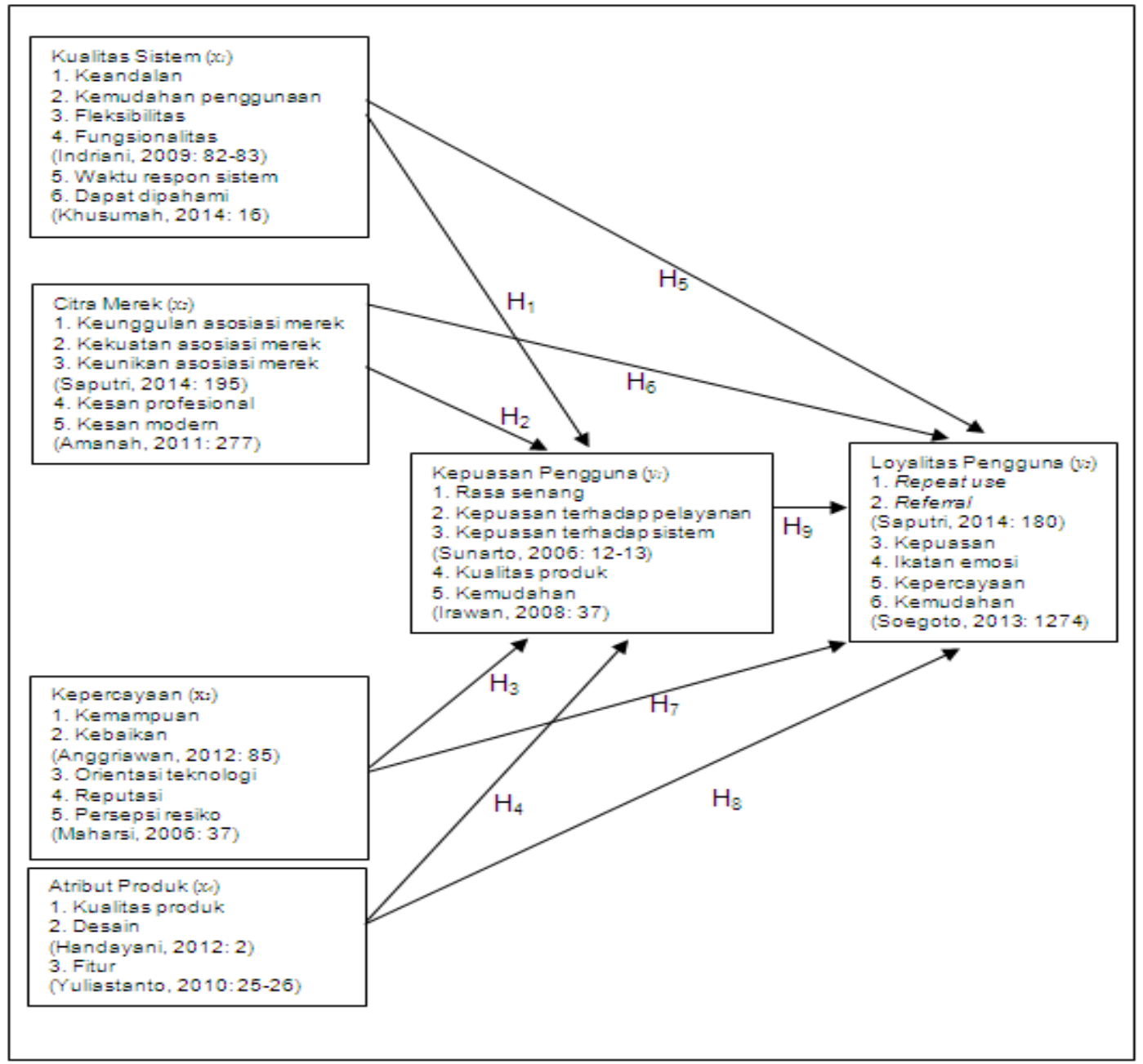

Gambar 1. Model Penelitian 
Pengaruh Kualitas Sistem terhadap Kepuasan Pengguna sistem aplikasi SNAPCHAT Kualitas sistem aplikasi informasi merupakan karakteristik dari informasi yang melekat mengenai sistem aplikasi itu. Dalam jurnal yang berjudul "Kualitas Sistem Informasi dan Kepuasan Pengguna Sistem Informasi Perguruan Tinggi Universitas Syiah Kuala", Indriani dan Adryan menyatakan bahwa variabel kualitas sistem berpengaruh secara langsung terhadap kepuasan pengguna. (Indriani, 2009: 90). Diprediksi bahwa semakin tinggi kualitas sistem aplikasi yang diberikan akan berpengaruh terhadap makin tingginya tingkat kepuasan pengguna. Atas dasar uraian di atas, maka penelitian ini mengajukan hipotesa pertama sebagai berikut :

Hipotesis H1 : Kualitas sistem berpengaruh terhadap kepuasan pengguna sistem aplikasi SNAPCHAT

\section{Pengaruh Kepercayaan terhadap Kepuasan Pengguna Sistem Aplikasi SNAPCHAT}

Kepercayaan adalah kesediaan perusahaan untuk bergantung pada mitra bisnis (Kotler, 2007). Menurut Stefhanie, Lisbeth dan Jantje dalam jurnalnya yang berjudul "Analisis Kualitas Layanan, Servicecape Dan Kepercayaan Terhadap Kepuasan Nasabah Pada PT. Bank Sinarmas Bitung" menyatakan bahwa kepercayaan secara parsial berpengaruh signifikan terhadap kepuasan nasabah. Apabila seorang pengguna merasa puas terhadap fasilitas yang diberikan oleh layanan sistem aplikasi secara terus menerus, maka perusahaan secara signifikan akan menambahkan rasa percaya atau ke[percayaan dari pengguna. Atas dasar dari uraian di atas, maka penelitian ini mengajukan hipotesa ketiga sebagai berikut:

Hipotesis H3 : Kepercayaan berpengaruh terhadap kepuasan pengguna sistem aplikasi SNAPCHAT

\section{Pengaruh Atribut Produk terhadap Kepuasan Sistem Aplikasi SNAPCHAT}

Menurut Muhammad Fauzul Hakim dalam jurnalnya yang berjudul "Pengaruh Atribut Produk Terhadap Kepuasan Pelanggan" menyatakan bahwa atribut produk (dengan indikator akeses koneksi, kualitas pelayanan dam harga) berpengaruh secara positif dan signifikan terhadap kepuasan konsumen. Diprediksi bahwa semakin baik atribut produk yang dihasilkan sistem aplikasi akan berpengaruh terhadap makin tingginya tingkat kepuasan pengguna. Atas dasar uraian di atas, maka penelitian ini mengajukan hipotesa keempat sebagai berikut:

Hipotesis H4 : Atribut Produk berpengaruh terhadap kepuasan pengguna sistem aplikasi SNAPCHAT

\section{Pengaruh Kualitas Sistem terhadap Loyalitas Pengguna}

Dalam penelitiannya Natalia mengungkapkan kualitas sistem berpengaruh positif terhadap loyalitas pengguna. Semakin tinggi kualitas sistem maka akan semakin tinggi loyalitas pengguna. (Natalia, 2015: 88). Diprediksi bahwa semakin tinggi kualitas sistem aplikasi yang diberikan akan berpengaruh terhadap makin tingginya loyalitas pengguna. Atas dasar uraian di atas, maka penelitian ini mengajukan hipotesa kelima sebagai berikut: Hipotesis H5 : Kualitas sistem berpengaruh terhadap loyalitas pengguna sistem aplikasi SNAPCHAT

\section{Pengaruh Citra Merek terhadap Loyalitas Pengguna Sistem Aplikasi SNAPCHAT}

Penelitian Saputri dan Pranata (Saputri, 2014: 200) mengungkapkan bahwa citra merek mempunyai pengaruh yang signifikan dan positif terhadap variabel dependen, yaitu loyalitas pelanggan.Hal serupa diungkapkan oleh Rimiyati dan Widodo (Rimiyati, 2014: 233) bahwa citra merek dengan variabel citra merek berpengaruh secara positif dan 
signifikan terhadap loyalitas konsumen. Diprediksi bahwa semakin baik citra merek suatu sistem aplikasi akan berpengaruh terhadap makin tingginya tingkat loyalitas pengguna.

Atas dasar uraian di atas, maka penelitian ini mengajukan hipotesa keenam sebagai berikut:

Hipotesis H6 : Citra merek berpengaruh terhadap loyalitas pengguna sistem aplikasi SNAPCHAT

\section{Pengaruh Kepercayaan terhadap Loyalitas Pengguna Sistem Aplikasi SNAPCHAT}

Dalam jurnal yang berjudul "Persepsi Nilai dan Kepercayaan Terhadap Kepuasan dan Dampaknya Terhadap Loyalitas Konsumen", Soegoto menyatakan kepercayaan memiliki pengaruh signifikan positif terhadap loyalitas konsumen. (Soegoto, 2013: 1280). Pendapat tersebut didukung dengan hasil penelitian yang dilakukan oleh Anggriawan dan Kridasusila yang menyatakan kepercayaan berpengaruh positif terhadap loyalitas pelanggan. (Anggriawan, 2012: 92). Diprediksi bahwa semakin tinggi tingkat kjepercayaan pengguna sistem aplikasi akan berpengaruh terhadap makin tingginya tingkat loyalitas pengguna. Atas dasar uraian di atas, maka penelitian ini mengajukan hipotesa ketujuh sebagai berikut:

Hipotesis $H 7$ : Kepercayaan berpengaruh terhadap loyalitas pengguna sistem aplikasi SNAPCHAT

\section{Pengaruh Atribut Produk terhadap Loyalitas Pengguna Sistem Aplikasi SNAPCHAT}

Dalam jurnal yang berjudul "Pengaruh Atribut Produk Terhadap Kepuasan Pelanggan dan Loyalitas Pelanggan", Nugroho mengungkapkan variabel atribut produk memiliki pengaruh terhadap variabel loyalitas pelanggan. Loyalitas pelanggan akan tercipta dengan adanya atribut produk, hal ini akan memicu pelanggan untuk selalu menggunakan maupun merekomendasikan produk tersebut kepada orang lain. (Nugroho, 2015: 6). Hal serupa diungkapkan oleh Yuliastanto dalam penelitiannya menghasilkan kesimpulan bahwa atribut produk memiliki pengaruh langsung yang positif dan signifikan terhadap loyalitas konsumen. Hal ini memberikan informasi bahwa jika atribut produk meningkat maka akan meningkatkan loyalitas konsumen. (Yuliastanto, 2010: 89)

Berdasarkan uraian diatas maka dirumuskan hipotesis kedelapan sebagai berikut:

Hipotesis H8 : Atribut Produk berpengaruh terhadap loyalitas penggunasistem aplikasi SNAPCHAT

\section{Pengaruh Kepuasan terhadap Loyalitas Pengguna Sistem Aplikasi SNAPCHAT}

Dalam jurnal "Pengaruh Citra Merek, Kualitas. Produk, Kepuasan Konsumen, Terhadap Loyalitas Konsumen Merek Samsung Galaxy Series", Rimiyati dan Widodo menyatakan bahwa kepuasan dengan variabel kepuasan berpengaruh secara positif dan signifikan terhadap loyalitas konsumen. (Rimiyati, 2014: 233). Pendapat tersebut didukung dengan hasil penelitian yang dilakukan oleh Anggriawan dan Kridasusila yang menyatakan kepuasan pelanggan berpengaruh positif terhadap loyalitas pelanggan. (Anggriawan, 2012: 90-91). Berdasarkan uraian diatas maka dirumuskan hipotesis kesembilan sebagai berikut:

Hipotesis H9 : Kepuasan berpengaruh terhadap loyalitas pengguna sistem aplikasi SNAPCHAT

\section{HASIL PENELITIAN DAN PEMBAHASAN}

Agar data yang diperoleh mempunyai tingkat akurasi dan konsistensi yang tinggi, maka instrumen penelitian yang digunakan harus valid dan reliabel (Sanusi, 2011). 


\section{Uji Validitas}

Uji validitas digunakan untuk mengetahui valid atau tidaknya suatu butir pertanyaan. Dalam penelitian ini, suatu butir pertanyaan dianggap valid jika nilai indeks (nilai factor loading) disemua indikator untuk semua varoiabel lebih besar dari 0.4.Hasil analisis validitas disajikan pada Tabel 1.

Tabel 1. Uji Validitas Variabel Kualitas Sistem

\begin{tabular}{|c|c|c|c|c|}
\hline Variabel & Indikator & $\begin{array}{c}\text { Nilai } \\
\text { Indeks }\end{array}$ & $\begin{array}{c}\text { Nilai Factor } \\
\text { Loading }\end{array}$ & Status \\
\hline \multirow[t]{6}{*}{ Kualitas Sistem } & Keandalan & 0,696 & $>0,4$ & Valid \\
\hline & Kemudahan Penggunaan & 0,710 & $>0,4$ & Valid \\
\hline & Fleksibilitas & 0,714 & $>0,4$ & Valid \\
\hline & Fungsionalitas & 0,725 & $>0,4$ & Valid \\
\hline & Waktu Respon Sistem & 0,730 & $>0,4$ & Valid \\
\hline & Dapat Dipahami & 0,767 & $>0,4$ & Valid \\
\hline \multirow[t]{5}{*}{ Citra Merek } & Keunggulan Asosiasi Merek & 0,727 & $>0,4$ & Valid \\
\hline & Kekuatan Asosiasi Merek & 0,756 & $>0,4$ & Valid \\
\hline & Keunikan Asosiasi Merek & 0,718 & $>0,4$ & Valid \\
\hline & Kesan Profesional & 0,794 & $>0,4$ & Valid \\
\hline & Kesan Modern & 0,711 & $>0,4$ & Valid \\
\hline \multirow[t]{5}{*}{ Kepercayaan } & Kemampuan & 0,747 & $>0,4$ & Valid \\
\hline & Kebaikan & 0,793 & $>0,4$ & Valid \\
\hline & Orientasi Teknologi & 0,693 & $>0,4$ & Valid \\
\hline & Reputasi & 0,742 & $>0,4$ & Valid \\
\hline & Persepsi Resiko & 0,781 & $>0,4$ & Valid \\
\hline \multirow[t]{3}{*}{ Atribut Produk } & Kualitas Produk & 0,841 & $>0,4$ & Valid \\
\hline & Desain & 0,855 & $>0,4$ & Valid \\
\hline & Fitur & 0,861 & $>0,4$ & Valid \\
\hline \multirow[t]{5}{*}{ Kepuasan Pengguna } & Rasa Senang & 0,808 & $>0,4$ & Valid \\
\hline & $\begin{array}{l}\text { Kepuasan Terhadap } \\
\text { Pelayanan }\end{array}$ & 0,778 & $>0,4$ & Valid \\
\hline & Kepuasan Terhadap Sistem & 0,856 & $>0,4$ & Valid \\
\hline & Kualitas Produk & 0,815 & $>0,4$ & Valid \\
\hline & Kemudahan & 0,783 & $>0,4$ & Valid \\
\hline \multirow[t]{6}{*}{ Loyalitas Pengguna } & Repeat Use & 0,813 & $>0,4$ & Valid \\
\hline & Referral & 0,797 & $>0,4$ & Valid \\
\hline & Kepuasan & 0,837 & $>0,4$ & Valid \\
\hline & Ikatan Emosi & 0,846 & $>0,4$ & Valid \\
\hline & Kepercayaan & 0,861 & $>0,4$ & Valid \\
\hline & Kemudahan & 0,801 & $>0,4$ & Valid \\
\hline
\end{tabular}

Dari tabel 1, hasil analisis data untuk 300 responden menunjukkan bahwa nilai indeks (factor loading) di semua indikator untuk semua variabel berada di atas 0,4 . Nilai, hasil korelasi jawaban responden disetiap item pertanyaan dengan nilai total jawaban responden menghasilkan nilai yang signifikan $(0,000)$, baik untuk variabel kualitas sistem, citra merek, kepercayaan, atribut produk, kepuasan dan loyalitas pengguna sistem aplikasi SNAPCHAT. Dengan demikian maka data kuisioner yang digunakan oleh masing-masing variabel dinyatakan valit sebagai alat ukur.

\section{Uji Reliabilitas}

Uji reliabilitas digunakan untuk menguji konsistensi data kuisioner yang merupakan indikator dari variabel. Suatu kuisioner dikatakan reliabel atau handal jika jawaban seseorang terhadap pernyataan adalah konsisten atau stabil dari waktu ke waktu ( Ghozali, 2009 ). Adapun alat yang digunakan untuk mengukur reliabilitas adalah koefisien Cronbach's Alpha. Suatu variabel dikatakan reliabel, apabila nilai Cronbach's Alpha > 0,6. 
Hasil uji reliabilitas di sajikan pada Tabel 2.

Tabel 2. Uji Reliabilitas

\begin{tabular}{|l|c|c|}
\hline \multicolumn{1}{|c|}{ Variabel } & Cronbach's Alpha & Status \\
\hline Kualitas Sistem & 0,818 & Reliabel \\
\hline Citra Merek & 0,795 & Reliabel \\
\hline Kepercayaan & 0,808 & Reliabel \\
\hline Atribut Produk & 0,812 & Reliabel \\
\hline Kepuasan Pengguna & 0,867 & Reliabel \\
\hline Loyalitas Pengguna & 0,907 & Reliabel \\
\hline
\end{tabular}

Hasil analisi data dari 300 responden menghasilkan nilai Cronbach's Alpha untuk variabel kualitas sistem, citra merk, kepercayaan, atribut produk, kepuasan pengguna dan loyalitas pengguna lebih besar dari 0.6. Dengan demikian, dapat disimpulkan bahwa kuisioner yang digunakan oleh masing-masing variavel penelitian terbukti handal atau reliabel yang menggambarkan konsistensi jawaban responden.

\section{Analisis Jalur (Path Analysis)}

Teknisl Analisis jalur yang dipakai dalam penelitian ini adalah kuantitatif dengan analisis jalur untuk menganalisis pola hubungan antar variabel dengan tujuan untuk mengetahui pengaruh langsung maupun tidak langsung seperangkat variabel bebas (eksogen) terhadap variabel terikat (endogen).

Analisis jalurnya adalah analisis jalur yang menggunakan regresi berganda dengan dua jalur persamaan. Persamaannya dapat dirumuskan sebagai berikut :

$y_{1}=\beta 1 x_{1}+\beta 2 x_{2}+\beta 3 x_{3}+\beta 4 x_{4}+\varepsilon_{1}$

$y_{2}=\beta 5 x_{1}+\beta 6 x_{2}+\beta 7 x_{3}+\beta 8 x_{4}+\beta 9 y_{1}+\varepsilon_{2}$

Keterangan :

$x_{1}=$ variabel kualitas sistem

$x_{2}=$ variabel citra merek

$x_{3} \quad=$ variabel kepercayaan

$x_{4} \quad=$ variabel atribut produk

$y_{1}=$ variabel kepuasan pengguna

$y_{2} \quad$ variabel loyalitas pengguna

$\beta i=$ koefisien variabel ke-i

$\varepsilon_{1}, \varepsilon_{2}=$ Residual

Hasil Analisis Regresi Berganda Kualitas Sistem, Citra Merek, Kepercayaan dan Atribut Produk terhadap Kepuasan Pengguna

\section{Uji T Rantai Kausal Pertama}

Uji T dilakukan untuk mengetahui apakah variabel kualitas sistem, citra merek, kepercayaan dan atribut produk secara parsial berpengaruh terhadap variabel kepuasan pengguna. Hasil analisis disajikan pada Tabel 3

Tabel 3. Uji T Rantai Kausal Pertama

\section{Coefficients $^{\mathrm{a}}$}

Model

\begin{tabular}{|c|c|c|c|c|}
\multicolumn{2}{|c|}{ Unstandardized Coefficients } & $\begin{array}{c}\text { Standardized } \\
\text { Coefficients }\end{array}$ & & \\
\cline { 1 - 3 } B & Std. Error & Beta & t & Sig. \\
\hline
\end{tabular}




\begin{tabular}{|l|l|r|r|r|r|r|}
\hline 1 & (Constant) &,- 153 &, 697 & &,- 220 &, 826 \\
\cline { 2 - 8 } & Total_KS &, 247 &, 044 &, 269 & 5,572 &, 000 \\
\cline { 2 - 8 } & Total_CM &, 167 &, 058 &, 159 & 2,883 &, 004 \\
\cline { 2 - 8 } & Total_KR &, 109 &, 048 &, 106 & 2,277 &, 024 \\
\cline { 2 - 8 } & Total_AP &, 732 &, 068 &, 448 & 10,80 &, 000 \\
& & & & 8 & \\
\hline
\end{tabular}

Berdasarkan tabel 3 dilihat bahwa variabel kualitas sistem memiliki nilai : $t_{\text {hitung }}=5.572>\mathrm{t}_{\text {tabel }}=1.650$ dan nilai signifikan sebesar $0.000<0.05$, maka dapat disimpulkan bahwa kualitas sistem berpengaruh secara signifikan terhadap kepuasan pengguna aplikasi Snapchat di kota Bandung.Variabel citra merek memiliki nilai $\mathrm{t}_{\text {hitung }} 2.883>\mathrm{t}_{\text {tabel }} 1.650$ dan nilai signifikan sebesar $0.004<0.05$, maka dapat disimpulkan bahwa citra merek berpengaruh secara signifikan terhadap kepuasan pengguna aplikasi Snapchat di kota Bandung. Variabel kepercayaan memiliki nilai $t_{\text {hitung }} 2.277>t_{\text {tabel }} 1.650$ dan nilai signifikan sebesar $0.024<0.05$, maka dapat disimpulkan bahwa kepercayaan berpengaruh secara signifikan terhadap kepuasan pengguna aplikasi Snapchat di kota Bandung. Variabel atribut produk memiliki nilai thitung10.808> $t_{\text {tabel }} 1.650$ dan nilai signifikan sebesar $0.000<0.05$, maka dapatdisimpulkan bahwa atribut produk berpengaruh secara signifikan terhadap kepuasan pengguna aplikasi Snapchat di kota Bandung.

\section{Hasil Analisis Regresi Berganda Kualitas Sistem, Citra Merek, Kepercayaan dan Atribut Produk dan kepuasan pengguna terhadap loyalitas Pengguna Uji T Rantai Kausal Kedua}

Uji T dilakukan untuk mengetahui apakah variabel kualitas sistem, citra merek, kepercayaan atribut produk, dan kepuasan secara parsial berpengaruh terhadap variabel loyalitas pengguna. Hasil analisis disajikan pada Tabel 4.

Tabel 4. Uji T Rantai Kausal Kedua

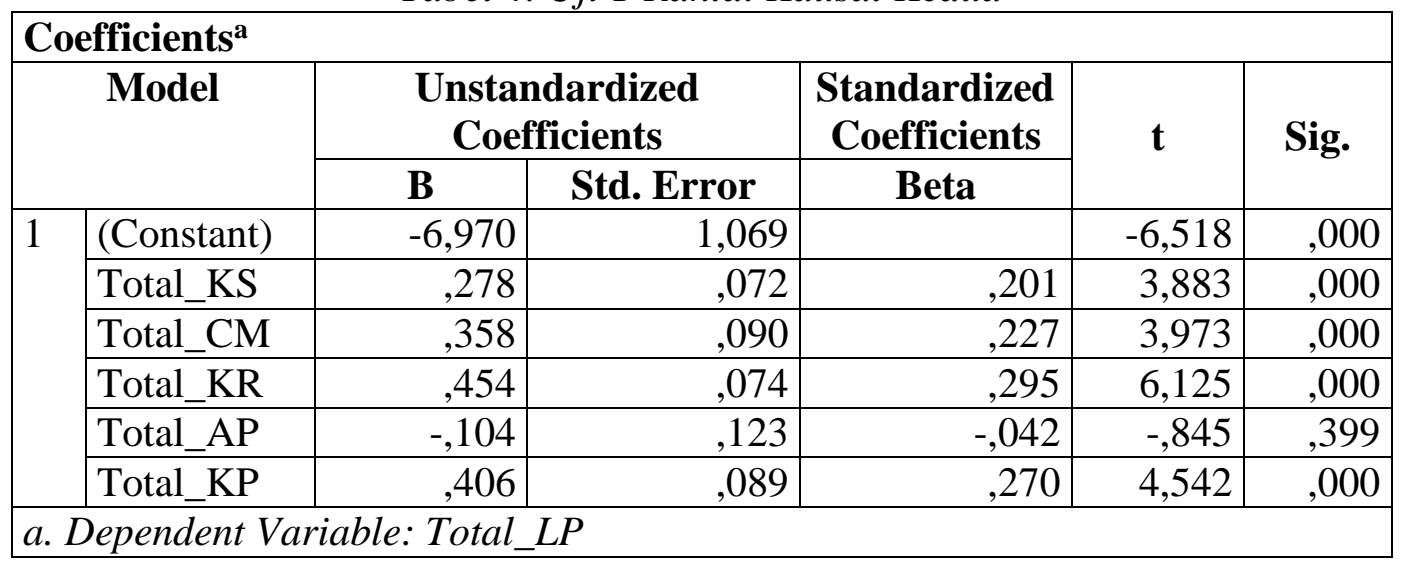

Hasil analisis yang diperoleh dari tabel 4 diperoleh bahwa :

Variabel kualitas sistem memiliki nilai thitung3.883> tabel 1.650 dan nilai signifikan sebesar $0.000<0.05$, maka dapat disimpulkan bahwa kualitas sistem berpengaruh secara signifikan terhadap loyalitas pengguna aplikasi Snapchat di kota Bandung. Variabel citra merek memiliki nilai $t_{\text {hitung } 3.973}>\mathrm{t}_{\text {tabel }} 1.650$ dan nilai signifikan sebesar $0.000<0.05$, maka dapat disimpulkan bahwa citra merek berpengaruh secara signifikan terhadap loyalitas pengguna aplikasi Snapchat di kota Bandung. Variabel kepercayaan memiliki nilai $t_{\text {hitung }} 6.125>t_{\text {tabel }}$ 1.650 dan nilai signifikan sebesar $0.000<0.05$, maka dapatdisimpulkan bahwa kepercayaan berpengaruh secara signifikan terhadap loyalitas pengguna aplikasi Snapchat di kota 
Bandung. Variabel atribut produk memiliki nilai $\mathrm{t}_{\text {hitung }} \mathrm{I}-0.845 \mathrm{I}<\mathrm{t}_{\text {tabel }} 1.650$ dan nilai signifikan sebesar 0.399>0.05, maka dapatdisimpulkan bahwa atribut produktidak berpengaruh secara signifikan terhadap loyalitas pengguna aplikasi Snapchat di kota Bandung.Variabel kepuasan memiliki nilai thitung $4.542>t_{\text {tabel }} 1.650$ dan nilai signifikan sebesar $0.000<0.05$, maka dapatdisimpulkan bahwa kepuasan berpengaruh secara signifikan terhadap loyalitas pengguna aplikasi Snapchat di kota Bandung.

\section{Model Analisis dan Persamaan Rantai Kausal Lengkap}

Hasil model analisis dan persamaan rantai kausal masing-masing selengkapnya dapat dilihat pada Gambar 2

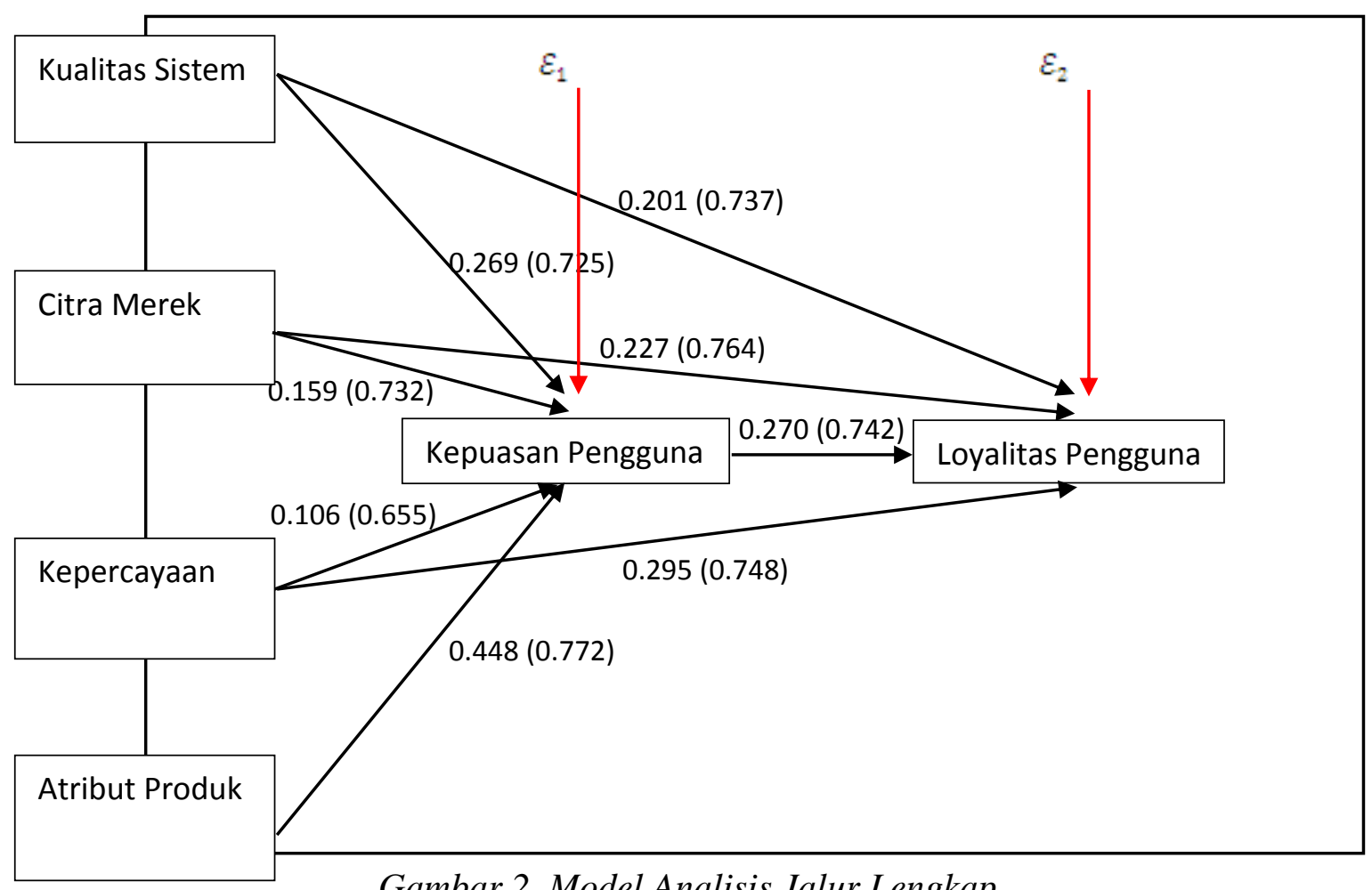

Gambar 2. Model Analisis Jalur Lengkap

\section{Rantai Kausal Pertama}

Persamaan linear dari hasil koefisien regresi antara kualitas sistem, citra merek, kepercayaan dan atribut produk dengan kepuasan pengguna ada;lah sebagai berikut:

$y_{1}=0.269 x_{1}+0.159 x_{2}+0.106 x_{3}+0.448 x_{4}+0.277$

Penjelasan dari persamaan regresi :

a. Koefisien regresi kualitas sistem sebesar 0.269. Nilai positif menunjukkan adanya peningkatan kualitas sistem akan diikuti peningkatan kepuasan pengguna.

Hubungan antara kualitas sistem dengan kepuasan adalah 0.725 (positif, hubungan kuat).

b. Koefisien citra merek sebesar 0.269. Nilai positif menunjukkan adanya peningkatan citra merek akan diikuti peningkatan kepuasan pengguna.

Hubungan antara citra merek dengan kepuasan adalah 0.732 (positif, hubungan kuat).

c. Koefisien kepercayaan sebesar 0.269. Nilai positif menunjukkan adanya peningkatan kepercayaan pengguna akan diikuti peningkatan kepuasan pengguna. Hubungan antara kepercayaan dengan kepuasan adalah 0.655 (positif, hubungan kuat). 
d. Koefisien atribut produk sebesar 0.269. Nilai positif menunjukkan adanya peningkatan atribut produk akan diikuti peningkatan kepuasan pengguna Hubungan antara atribut produk dengan kepuasan adalah 0.772 (positif, hubungan kuat).

\section{Rantai Kausal Kedua}

Persamaan linear dari hasil koefisien regresi antara kualitas sistem, citra merek, kepercayaan, atribut produk, dan kepuasan pengguna terhadap loyalitas pengguna sebagai berikut:

$y_{2}=0.201 x_{1}+0.227 x_{2}+0.295 x_{3}+0.270 y_{1}+0.288$

Penjelasan Model rantai kausal kedua adalah :

a. Kualitas sistemterhadap loyalitas pengguna

Kualitas sistem memberi pengaruh langsung pada loyalitas sebesar 0.201. Hubungan antara kualitas sistem dengan loyalitas adalah 0.737 (positif, hubungan kuat).

b. Citra merekterhadap loyalitas pengguna

Citra merek memberi pengaruh langsung pada loyalitas sebesar 0.227. Hubungan antara kualitas sistem dengan loyalitas adalah 0.764 (positif, hubungan kuat).

c. Kepercayaanterhadap loyalitas pengguna

Kepercayaan memberi pengaruh langsung pada loyalitas sebesar 0.295. Hubungan antara kualitas sistem dengan loyalitas adalah 0.748 (positif, hubungan kuat).

d. Kepuasan terhadap loyalitas pengguna

Kepuasan memberi pengaruh langsung pada loyalitas sebesar 0.270. Hubungan antara kepuasan dengan loyalitas adalah 0.742 (positif, hubungan kuat).

\section{Uji F Rantai Kausal Pertama}

Uji F digunakan untuk mengetahui apakah variabel kualitas sistem, citra merek, kepercayaan dan atribut produk secara bersama-samaberpengaruh terhadap kepuasan pengguna aplikasi Snapchat. Berikut ini adalah hasil pengujian uji F.

Hasil analisis uji $\mathrm{F}$ dapat dilihat pada tabel 5

Tabel 5. Uji F Rantai Kausal Pertama

\begin{tabular}{|l|r|r|r|r|r|r|}
\hline \multicolumn{7}{|c|}{ ANOVA $^{\text {b }}$} \\
\hline \multicolumn{2}{|c|}{ Model } & $\begin{array}{c}\text { Sum of } \\
\text { Squares }\end{array}$ & \multicolumn{1}{c|}{ Df } & $\begin{array}{c}\text { Mean } \\
\text { Square }\end{array}$ & F & Sig. \\
\hline \multirow{2}{*}{1} & Regression & 2377,985 & 4 & 594,496 & 196,167 &, $000^{\mathrm{a}}$ \\
\cline { 2 - 7 } & Residual & 894,015 & 295 & 3,031 & & \\
\cline { 2 - 6 } & Total & 3272,000 & 299 & & & \\
\hline
\end{tabular}

Berdasarkan hasil pengolahan uji F pada tabel 5 dilihat bahwa nilai $f_{\text {hitung }} 196.197>$ $\mathrm{f}_{\text {tabel }} 2.40$ dan nilai signifikan $0.000<0.05$, maka dapat disimpulkan bahwa kualitas sistem, citra merek, kepercayaan dan atribut produk secara bersama-samaberpengaruh terhadap kepuasan pengguna aplikasi Snapchat di kota Bandung.

\section{Uji F Rantai Kausal Kedua}

Uji $\mathrm{F}$ digunakan untuk mengetahui apakah variabel kualitas sistem, citra merek, kepercayaan, atribut produk, dan kepuasan pengguna secara bersama-samaberpengaruh terhadap loyalitas pengguna aplikasi Snapchat. 
Hasil analisis uji $\mathrm{F}$ dapat dilihat pada tabel 6

Tabel 6. Uji F Rantai Kausal Kedua

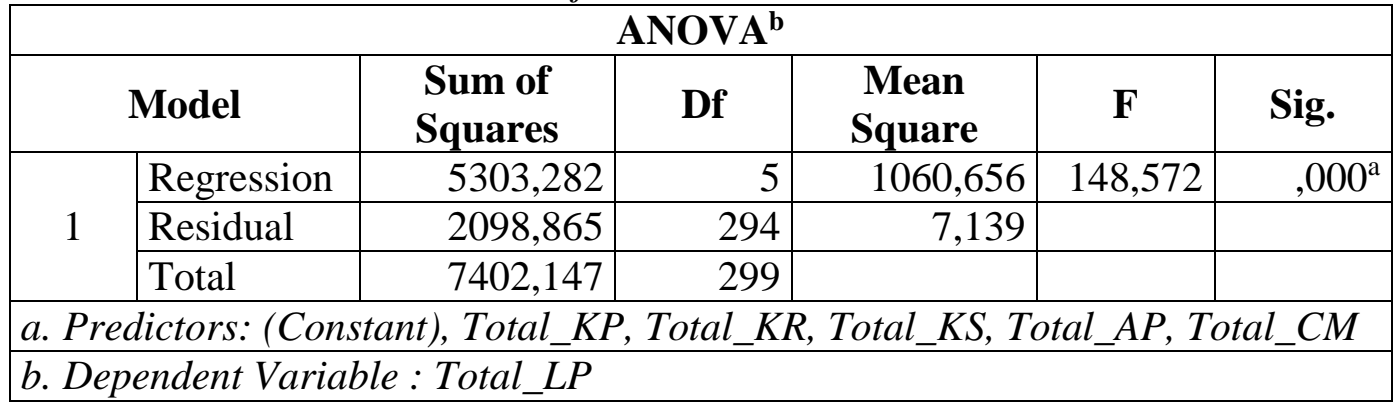

Berdasarkan hasil pengolahan uji F pada tabel 6 dilihat bahwa nilai $f_{\text {hitung }} 148.572>$ $\mathrm{f}_{\text {tabel }} 2.24$ dan nilai signifikan $0.000<0.05$, maka dapat disimpulkan bahwa kualitas sistem, citra merek, kepercayaan, atribut produkdan kepuasan bersama-sama tidak berpengaruh terhadap loyalitas pengguna aplikasi Snapchat di kota Bandung.

\section{Koefisisen Determinasi}

Koefisien determinasi untuk mengetahui seberapa besar pengaruh secara bersamasama semua variabel bebas terhadap variabel terikat.

\section{Koefisien Determinasi Rantai Kausal Pertama}

Koefisien determinasi rantai kausal pertama dapat dilihat pada Tabel 7.

Tabel 7. Koefisien Determinasi Rantai Kausal Pertama Model Summary ${ }^{b}$

\begin{tabular}{|l|c|c|c|c|c|}
\hline \multicolumn{2}{|c|}{ Model } & $\mathbf{R}$ & R Square & $\begin{array}{c}\text { Adjusted R } \\
\text { Square }\end{array}$ & $\begin{array}{c}\text { Std. Error of the } \\
\text { Estimate }\end{array}$ \\
\hline dimension0 & 1 &, $853^{\mathrm{a}}$ &, 727 &, 723 & 1,74085 \\
\hline
\end{tabular}

Nilai Adjusted $R$ Square sebesar 0.723, menunjukkan bahwa sebesar $72.3 \%$ kepuasan pengguna dipengaruhi oleh kualitas sistem, citra merek, kepercayaan dan atribut produk, sisanya sebesar $27.7 \%$ dipengaruhi oleh variabel lain diluar model regresi dalam penelitian ini.

\section{Koefisien determinasi rantai kausal kedua}

Tabel 8. Koefisien Determinasi Rantai Kausal Pertama Model Summary ${ }^{b}$

\begin{tabular}{|c|c|c|c|c|}
\hline Model & $\mathbf{R}$ & R Square & $\begin{array}{c}\text { Adjusted R } \\
\text { Square }\end{array}$ & $\begin{array}{l}\text { Std. Error of the } \\
\text { Estimate }\end{array}$ \\
\hline \begin{tabular}{l|l} 
dimension0 & 1 \\
\end{tabular} &, $846^{\mathrm{a}}$ & ,716 &, 712 & 2,67189 \\
\hline \multicolumn{5}{|c|}{ a. Predictors: (Constant), Total_KP,Total_KR,Total_KS,Total_AP,otal_CM } \\
\hline \multicolumn{5}{|c|}{ b. Dependent Variable: Total_LP } \\
\hline
\end{tabular}

Nilai Adjusted $R$ Square sebesar 0.712, menunjukkan bahwa sebesar 71.2\% loyalitas pengguna dipengaruhi oleh kualitas sistem, citra merek, kepercayaan, atribut produk dan kepuasan pengguna, sisanya sebesar $28.8 \%$ dipengaruhi oleh variabel lain diluar model regresi dalam penelitian ini.

\section{Pengaruh Tidak Langsung}

Besarnya pengaruh tidak langsung antar variavel dapat ditentukan dengan mengalikan koefisien variabel pada persamaan jalur pertama dengan koefisien jalur 
variabel kepuasan terhadap loyalitas. Hasil dari perhitungan pengaruh tidak langsung dapat dilihat pada Tabel 9.

Tabel 9. Pengaruh Tidak Langsung

\begin{tabular}{|l|c|c|c|}
\hline \multicolumn{1}{|c|}{ Variabel } & Koefisien Jalur & $\begin{array}{c}\text { Koefisien Jalur Variabel } \\
\text { Kepuasan }\end{array}$ & $\begin{array}{c}\text { Pengaruh Tidak } \\
\text { Langsung }\end{array}$ \\
\hline Kualitas Sistem & 0,269 & 0,270 & 0,073 \\
\hline Citra Merek & 0,159 & 0,270 & 0,043 \\
\hline Kepercayaan & 0,106 & 0,270 & 0,029 \\
\hline Atribut Produk & 0,448 & 0,270 & 0,121 \\
\hline
\end{tabular}

Berdasarkan tabel 9 pengaruh tidak langsung antara variabel kualitas sistem, citra merek, kepercayaan dan atribut produk terhadap loyalitas melalui kepuasan, yaitu :

a. Kualitas sistem memberi pengaruh tidak langsung pada loyalitas melalui kepuasan sebesar $0.269 \times 0.270=0.073$ atau $7.3 \%$.

b. Citra merek memberi pengaruh tidak langsung pada loyalitas melalui kepuasan sebesar $0.159 \times 0.270=0.043$ atau $4.3 \%$.

c. Kepercayaan memberi pengaruh tidak langsung pada loyalitas melalui kepuasan sebesar $0.106 \times 0.270=0.029$ atau $2.9 \%$.

d. Atribut produk memberi pengaruh tidak langsung pada loyalitas melalui kepuasan sebesar $0.448 \times 0.270=0.121$ atau $12.1 \%$

\section{KESIMPULAN}

Dari hasil penelitian mengenai analisis pengaruh kualitas sistem, citra merek, kepercayaan dan atribut produk terhadap kepuasan dan dampaknya terhadap loyalitas pengguna aplikasi Snapchat di kota Bandung, maka dapat diambil kesimpulan sebagai berikut :

a. Kualitas sistem berpengaruh signifikan terhadap kepuasan pengguna. Dengan demikian maka dapat disimpulkan bahwa adanya peningkatan kualitas sistem maka akan meningkatkan kepuasan pengguna.

b. Citra merek berpengaruh signifikan terhadap kepuasan pengguna. Dengan demikian maka dapat disimpulkan bahwa adanya peningkatan citra merek maka akan meningkatkan kepuasan pengguna.

c. Atribut produk berpengaruh signifikan terhadap kepuasan pengguna. Dengan demikian maka dapat disimpulkan bahwa adanya peningkatan atribut produk maka akan meningkatkan kepuasan pengguna.

d. Kepercayaan berpengaruh signifikan terhadap kepuasan pengguna. Dengan demikian maka dapat disimpulkan bahwa adanya peningkatan kepercayaan maka akan meningkatkan kepuasan pengguna.

e. Kualitas sistem berpengaruh signifikan terhadap loyalitas pengguna. Dengan demikian maka dapat disimpulkan bahwa adanya peningkatan kualitas sistem maka akan meningkatkan loyalitas pengguna.

f. Citra merek berpengaruh signifikan terhadap loyalitas pengguna. Dengan demikian maka dapat disimpulkan bahwa adanya peningkatan citra merek maka akan meningkatkan loyalitas pengguna.

g. Atribut produk berpengaruh signifikan terhadap loyalitas pengguna. Dengan demikian maka dapat disimpulkan bahwa adanya peningkatan atribut produk maka akan meningkatkan loyalitas pengguna.

h. Kepercayaan berpengaruh signifikan terhadap loyalitas pengguna. Dengan demikian maka dapat disimpulkan bahwa adanya peningkatan kepercayaan maka akan meningkatkan loyalitas pengguna. 
i. Kepuasan berpengaruh signifikan terhadap loyalitas pengguna. Dengan demikian maka dapat disimpulkan bahwa adanya peningkatan kepuasan maka akan meningkatkan loyalitas pengguna.

j. Kualitas sistem memberi pengaruh tidak langsung pada loyalitas melalui kepuasan sebesar $0.269 \times 0.270=0.073$ atau $7.3 \%$.

k. Citra merek memberi pengaruh tidak langsung pada loyalitas melalui kepuasan sebesar $0.159 \times 0.270=0.043$ atau $4.3 \%$.

1. Kepercayaan memberi pengaruh tidak langsung pada loyalitas melalui kepuasan sebesar $0.106 \times 0.270=0.029$ atau $2.9 \%$.

m. Atribut produk memberi pengaruh tidak langsung pada loyalitas melalui kepuasan sebesar $0.448 \times 0.270=0.121$ atau $12.1 \%$.

\section{DAFTAR PUSTAKA}

Amanah, Dita. 2011. Pengaruh Promosi dan Brand Image (Citra Produk) terhadap Loyalitas Pembelian Produk Pepsodent di Ramayana Plaza Jalan Aksara Medan, Jurnal Keuangan dan Bisnis Volume 3 No.3.

Anggriawan, Feriey, dan Andy Kridasusila. 2012. Pengaruh Kepuasan, Kepercayaan dan Komitmen terhadap Loyalitas Pelanggan (Studi Pada Kuch2HoTahu di Alfa Jl. Fatmawati Raya Semarang), Jurnal Dinamika Manajemen Vol.2, No.1. Semarang: Universitas Semarang.

Ghozali, Imam. 2006. Aplikasi Multivariat dengan Program SPSS. Semarang: Badan Penerbit Universitas Diponegoro.

Hakim, Muhammad Fauzul. 2015. Pengaruh Atribut Produk Terhadap Kepuasan Pelanggan. Yogyakarta: Universitas Negeri Yogyakkarta.

Handayani, Novita Tri. 2012. Pengaruh Atribut Produk Terhadap Loyalitas Pelanggan Green Product Sepeda Motor Honda Injection, Management Analysis Journal 1 (2). Semarang: Universitas Negeri Semarang.

Indriani, Mirna, dan Reza Adryan. 2009. Kualitas Sistem Informasi dan Kepuasan Pengguna Sistem Informasi Perguruan Tinggi Universitas Syiah Kuala, Jurnal Telaah \& Riset Akuntansi Vol.2, No.1. Banda Aceh: Universitas Syiah Kuala.

Irawan, Handi. 2008. Sepuluh Prinsip Kepuasan Pelanggan. Jakarta: PT Elex Media Komputindo

Khusumah, Samantha. 2014. Analisis Pengaruh Kualitas Sistem Informasi, Manfaat, Resiko, Keamanan dan Pelayanan Pemesanan Tiket Online PT Kereta Api Indonesia Terhadap Kepuasan Pelanggan. Bandung: STMIK LIKMI.

Kotler, Philip, dan Kevin Lane Keller. 2007. Manajemen Pemasaran Edisi 12 Jilid 1. Jakarta: Indeks-Prentice Hall.

Mustakini, Jogiyanto Hartono. 2009. Perancangan Sistem Informasi Pengenalan Komputer. Yogyakarta:Pustaka Pelajar. 
Nugroho, Nokma Aditya, Suharyono, dan Sunarti. 2015. Pengaruh Atribut Produk Terhadap Kepuasan Pelanggan dan Loyalitas Pelanggan (Survei pada Counter Perdana di Gresik), Jurnal Administrasi Bisnis (JAB) Vol. 20, No. 1. Malang: Universitas Brawijaya.

Maharsi, Sri, dan Fenny. 2006. Analisa Faktor-Faktor yang mempengaruhi Kepercayaan dan Pengaruh Kepercayaan Terhadap Loyalitas Pengguna Internet Banking di Surabaya, Jurnal Akutansi dan Keuangan Vo. 8 No.1. Surabaya: Universitas Kristen Petra.

Rimiyati, Hasnah, dan Catur Widodo. 2014. Pengaruh Citra Merek, Kualitas Produk, Kepuasan Konsumen, Terhadap Loyalitas Konsumen Merek Samsung Galaxy Series. Yogyakarta: Universitas Muhammadiyah Yogyakarta.

Saputri, Maharani Eka, dan Tutut Ratna Pranata. 2014. Pengaruh Brand Image Terhadap Kesetiaan Pengguna Smartphone Iphone, Jurnal Sosioteknologi Volume 13, Nomor 3. Bandung: Universitas Telkom.

Sari, Stefanny Ratna. 2013. Pengaruh Kepuasan Pelanggan, Kepercayaan Pelanggan dan Switching Barriers Terhadap Loyalitas Pelanggan Hartono Elektronika Surabaya, Jurnal. Surabaya: Universitas Katolik Widya Mandala.

Soegoto, Agus Supandi. 2013. Persepsi Nilai dan Kepercayaan Terhadap Kepuasan dan Dampaknya Terhadap Loyalitas Konsumen, Jurnal EMBA Vol.1, No.3. Manado: Universitas Sam Ratulangi.

Sunarto. 2006. Analisis Faktor-Faktor yang Mempengaruhi Loyalitas Pelanggan dan Dampaknya Terhadap Keunggulan Bersaing (Studi pada Tabungan Britama BRI Kanca Kendal). Semarang: Universitas Diponegoro.

Sutabri, Tata. 2012. Konsep Dasar Informasi. Yogyakarta: Andi.

Yuliastanto, Anggi Pratama. 2010. Pengaruh Kualitas Pelayanan dan Atribut Produk Terhadap Loyalitas Konsumen dengan Kepuasan Konsumen Sebagai Variabel Intervening (Studi Kasus pada Kurnia Stadium Boyolali). Semarang: Universitas Negeri Semarang. 